(Continued from preceding page)

formed in 1930, all these properties were a part of the merger.

One of the first moves by Republic was to set up Grand Crossing for the production of spring wire. Later, in 1935, it was decided that the Chicago plants, situated in the midwest where there are good markets for steel fence, should re-enter the farm product field. Consequently, a new wire mill was designed and built at South Chicago to meet the special needs of rural markets. The results of long research by electrical, chemical, metallurgical, mechanical, and civil engineers had been pooled in this modern mill; one of its outstanding features is a huge electrogalvanizing unit that coats as much as 867 miles of fence wire with pure zinc in a single day.

In 1946 the open hearth and electric furnace alloy steel plant, engineered and built by Republic during the war for the Defense Plant Corp., was purchased.
This plant was designed specifically for the production of electric furnace steels and is completely integrated from the ore and coal docks to the rolling mills and shipping departments. It is a unique arrangement of steelmaking equipment so planned that a systematic and direct flow is obtained throughout the entire process from iron ore to finished product. Nine electric furnaces in the same melt shop with four basic open hearth furnaces make possible the production of highest quality steels with maximum efficiency from the available raw materials. At present, steel and steel products ranging from nails to large, high-quality, alloy steel blooms are made for shipment throughout the Middle West.

Republic's South Chicago steel plant, one of the nation's most modern basic steel plants, is the second largest steel plant in South Chicago, with an annual ingot capacity of $1,769,000$ tons. It is the fifth largest plant in the Chicago-Northern Indiana areathe world's largest steelmaking complex.

\title{
CONTROLLED PRESSURE POURING \\ At Washington Steel Corp.
}

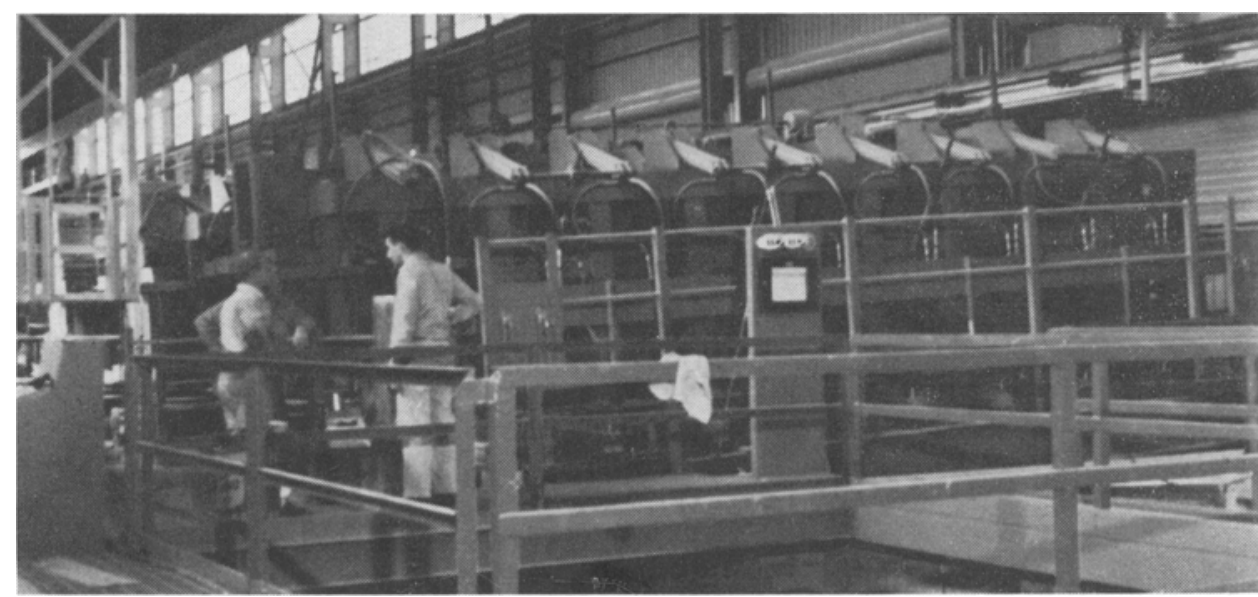

Controlled Pressure Pouring of stainless steel slabs is the feature of Washington Steel Corp.'s new melt shop near Washington, Pa. Soon to be on stream, it will be the first fully commercial unit of its kind. Above and below are shown the graphite slab molds.

Below-One of two 35-ton Lectromelt furnaces at Washington Steel's new melt shop.
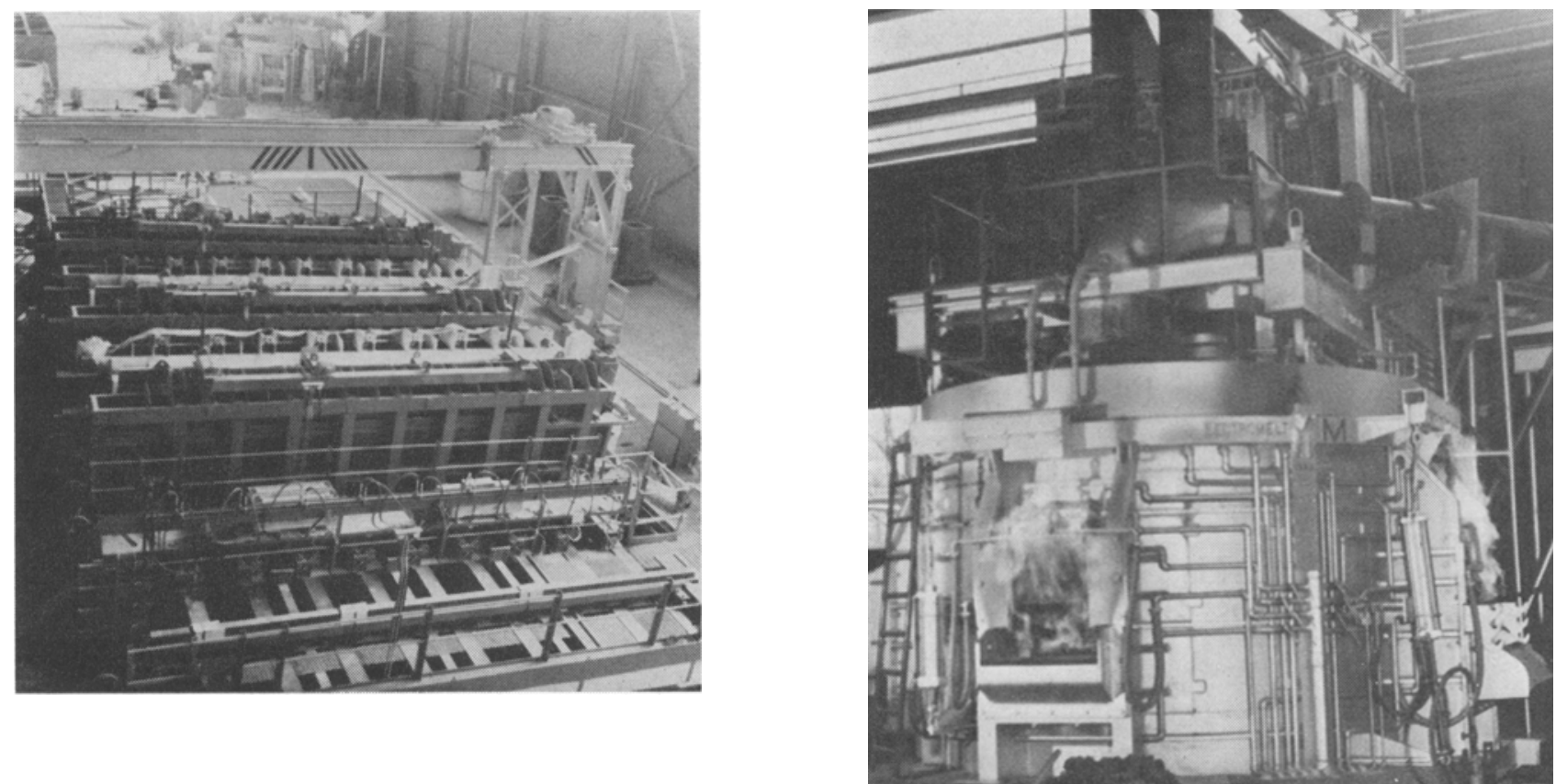